\title{
Effect of integrated nitrogen management through organic and inorganic sources on the yield of rice (Oryza sativa L.) and status of soil fertility at harvest
}

\section{Harish Shenoy*}

Department of Botany, University College, Mangalore, Mangalore University, Mangalore575001 (Karnataka), India.

Siddaraju. M. N.

Department of Botany, University College, Mangalore, Mangalore University, Mangalore575001 (Karnataka), India.

${ }^{*}$ Corresponding author. Email: harish.shenoy1@gmail.com

\author{
Article Info \\ https://doi.org/10.31018/ \\ jans.v12i4.2433
}

Received: November 4, 2020

Revised: December 11, 2020

Accepted: December 14, 2020

\section{How to Cite}

Shenoy H. and Siddaraju. M. N. (2020). Effect of integrated nitrogen management through organic and inorganic sources on the yield of rice (Oryza sativa L.) and status of soil fertility at harvest. Journal of Applied and Natural Science, $12(4): 721$ - 727. https://doi.org/10.31018/jans.v12i4.2433

\begin{abstract}
The present investigation was conducted with the objective of utilizing locally available organic resources for substituting chemical fertilizer nitrogen partly and augmenting soil health. The experiment was carried out for the crop kharif rice (Oryza sativa L.) in coastal Karnataka with eleven treatments laid out in randomized block design with three replications. Vermicompost (VC), Poultry manure (PM) and Fish manure (FM) were used as organic nitrogen sources integrated with mineral nitrogen source of fertilizer urea at substitution ratios of 25,50 and 100 percent. These treatments were compared with control and recommended dose of nitrogen. The results revealed that the substitution of 50 per cent of nitrogen through VC recorded significantly $(P<0.05)$ higher plant height $(92.27 \mathrm{~cm})$, higher number of productive tillers $\left(16.85\right.$ hill $\left.^{-1}\right)$, higher grain yield $\left(5434 \mathrm{~kg} \mathrm{ha}^{-1}\right)$ and straw yield $\left(6817 \mathrm{~kg} \mathrm{ha}^{-1}\right.$ ) compared to control. The results of the soil sample analysis for soil fertility parameters indicated that the major nutrients were significantly $(P<0.05)$ influenced by integrated nitrogen management. The available nitrogen $\left(382.36 \mathrm{~kg} \mathrm{ha}^{-1}\right)$ and available potassium $\left(143.7 \mathrm{~kg} \mathrm{ha}^{-1}\right)$ were significantly $(P<0.05)$ higher in the treatment $\mathrm{T} 4$ where a recommended dose of nitrogen was substituted by 50 percent VC compared to control $\left(294.05 \mathrm{~kg} \mathrm{ha}^{-1}\right.$ and $92.31 \mathrm{~kg} \mathrm{ha}^{-1}$ respectively). However, the available soil phosphorus was significantly higher with treatment 50 per cent RDN substituted by PM $\left(78.83 \mathrm{~kg} \mathrm{ha}^{-1}\right)$ as compared to control $\left(43.93 \mathrm{~kg} \mathrm{ha}{ }^{-1}\right)$. Thus, integrated resource management improved crop yield and post-harvest soil fertility.
\end{abstract}

Keywords: Fish manure, Poultry manure, Rice, Soil Fertility, Vermicompost

\section{INTRODUCTION}

Rice (Oryza sativa $L$ ) is one of the important cereal crops of the world occupying $11 \%$ of the agricultural land and ranks second in terms of cultivated area (Tumrani et al., 2015). Globally rice is grown on an area of 162 million ha with a production of 461 million tons and productivity is 4.09 tons per ha (Anonymous, 2015). Rice is life for almost half of the global population and the majority of the Indian people. The living and livelihood of the majority of the Indian farming population also depend on growing rice. In India, the rice is grown in an area of 43.19 million ha with a production of 110.15 million tons. (Anonymous, 2017). Rice production in India has increased almost threefold over the last five decades and contributes handsomely to the nutritional security of the country. Though rice production continues to play a vital role in the national food and livelihood security of the Indian system, the productivity of rice is only $2.55 \mathrm{t} / \mathrm{ha}$ (milled rice) which is less compared to global productivity of $3.28 \mathrm{t} / \mathrm{ha}$ (Anonymous,2018).

The growing population demands a reorientation of the research efforts in rice-based agricultural production systems to ensure higher productivity with less land, less water, and less labour, with environmentfriendly technologies that are more resilient to climate change and minimize environmental footprints. Increasing the productivity of rice remains the main challenge considering that $90 \%$ of the cultivated area of rice belong to small and marginal farmers. The most feasible way by which this could be achieved is by adopting a more integrated approach involving water, nutrients and other agronomic factors for maximizing the rice grain yield (Gobi et al., 2016). Fertilizers have contributed substantially to nearly $50 \%$ of rice 
varietal yield potential. However, continuous use of inorganic fertilizers alone causes soil organic matter degradation, soil acidity and environmental pollution (Shipra et al., 2019).

Nitrogen $(N)$ is the essential nutrient element, which plays a crucial role in enhancing the yield in rice by promoting rapid plant growth and improving quality (Prathap et al., 2019). Hence provision of an adequate supply of $\mathrm{N}$ throughout the growing period is essential for realizing potential yields (Sureka et al., 2016). Globally rice cultivation consumes approximately 9-10 million tons of fertilizer nitrogen in a year which accounts for about 10 per cent of the total nitrogen fertilizer production in the world (Nayak et al., 2018). Though the yield increase due to nitrogen fertilization in rice has been substantial (47 per cent), the average agronomic efficiency of nitrogen is only $11.4 \mathrm{~kg}$ grain/ $\mathrm{kg} \mathrm{N}$ (Prasad, 2011) and nitrogen use efficiency is only (30-50\%) due to losses of nitrogen under the flooded condition in the form of volatilization, denitrification and leaching (Prasad et al., 2014). Achieving high nitrogen use efficiency in rice production has become a major challenge with increasing food demand, depletion of natural resources and environmental deterioration. Therefore, the development of efficient $\mathrm{N}$ management strategy for sustaining soil fertility and maximizing crop yields by partially substituting the chemical $\mathrm{N}$ fertilizers with suitable organic sources like farmyard manure, poultry manure, vermicompost, green manuring, neem cake and biofertilizers is gaining importance (Dahiphale et al., 2003). Little information is available regarding rice yield responses to organic substitution fertilizer regimes (in which one or more organic $\mathrm{N}$ substitution ratios are employed). Therefore, efforts to clarify the influences of organic substitution regimes under different organic-inorganic substitution ratios are needed to be developed for effective fertilizer management strategies. Soil fertility fluctuates throughout the growing season each year due to alteration in the quantity and availability of mineral nutrients by addition of organic and inorganic sources. Hence evaluation of soil fertility status of the rice field is essential for maintaining optimum fertility in the soil. Though many integrated nutrient management and soil fertility studies have been carried out in rice, locationspecific studies for coastal Karnataka is lacking. Therefore, the present investigation was carried out to study the effect of organic and inorganic sources of nitrogen under different substitution ratios on rice yield and soil fertility status at harvest during kharif season in coastal Karnataka.

\section{MATERIALS AND METHODS}

The investigation was carried out in June-2017 during kharif season at the instructional farm of ICAR-Krishi Vigyan Kendra (KVK), Mangaluru of Karnataka state to study the response of rice (Oryza sativa L.) to the integrated application of an organic and inorganic source of nitrogen and assess its effect on the soil fertility status at harvest. The soil of the experimental site was lateritic characterized by acidic $\mathrm{pH}$ (5.5) having Electrical Conductivity (EC) of $0.14 \mathrm{dSm}^{-1}$. The soil of the experimental field before experimentation contained medium available nitrogen $(380 \mathrm{~kg} / \mathrm{ha})$, high available phosphorus ( $97.4 \mathrm{~kg} / \mathrm{ha}$ ) and low available potassium was $(96.13 \mathrm{~kg} / \mathrm{ha})$. The experiment was laid out in a randomized block design (RBD) with three replications. There were eleven treatments comprising of $\mathrm{T} 1=$ Control, $\mathrm{T} 2=$ =Package of practices(POP) recommended dose of fertilizers(RDF) @ 60 kg N ha ${ }^{-1}, 30$ $\mathrm{kgP}_{2} \mathrm{O}_{5} \mathrm{ha}^{-1}$ and $60 \mathrm{~kg} \mathrm{~K}_{2} \mathrm{O} \mathrm{ha}^{-1}$, T3=POP $+25 \%$ Recommended dose of Nitrogen (RDN) substitution through Vermicompost(VC), T4=POP $+50 \% \quad$ (RDN) substitution through VC, T5=POP $+25 \%$ RDN substitution through Poultry Manure(PM), T6=POP $+50 \%$ RDN substitution through PM, T7=POP $+25 \%$ RDN substitution through Fish Manure(FM),T8=POP $+25 \%$ RDN substitution through FM, T9= POP $+100 \%$ RDN substitution through VC, T10 $=$ POP $+100 \%$ RDN substitution through PM, T11 $=$ POP $+100 \%$ RDN substitution through FM. Well decomposed poultry manure, vermicompost and fish manure were used as organic sources for nitrogen. Based on the equal $\mathrm{N}$ basis, required quantities of organic manures were incorporated in the soil 10 days before puddling. In the treatment T2, recommended doses of 60:30:60 kg ha- ${ }^{1}$ of $\mathrm{N}, \mathrm{P}$ and $\mathrm{K}$ in the form of urea $(46 \% \mathrm{~N})$, Rock Phosphate $\left(20 \% \mathrm{P}_{2} \mathrm{O}_{5}\right)$ and Muriate of potash $\left.60 \% \quad \mathrm{~K}_{2} 0\right)$ were applied to the rice crop. The source of nitrogen used was urea $(46 \% \mathrm{~N})$ applied in three split dose (33\% each) at planting, tillering and panicle initiation stage. The entire dose of phosphorus was applied as basal dose before sowing. Half of the potassium was applied as basal at planting and the remaining half was applied at two splits at maximum tillering and panicle initiation stage. The popular rice variety, MO -4 (Bhadra) was raised in the nursery in June-2017, and twenty-one day old seedlings were transplanted on 01-07-2017 using two seedlings hill ${ }^{-1}$ with a spacing of $20 \mathrm{~cm} \times 15 \mathrm{~cm}$. Recommended agronomic practices and plant protection measures were followed.

Characterization of surface soil for fertility status was studied by taking representative soil samples at random at a depth of $15.0 \mathrm{~cm}$ from treatment plots after harvest. The collected soil samples were analyzed for $\mathrm{pH}, \mathrm{EC}$ and available major nutrients. Standard procedures were adopted for analysis of the nutrients in the laboratory. During the period of crop growth from June to October 2017, total rainfall of $2792 \mathrm{~mm}$ was received as against normal rainfall of $3245 \mathrm{~mm}$ for the same period. Bio-metric observations for growth and yield attributes of rice were recorded at harvest. The data was analyzed statistically following analysis of variance as suggested by Gomez and Gomez (1984), and treatment means were compared based on the 
Least Significant Difference (LSD) at 5 per cent probability level.

\section{RESULTS AND DISCUSSION}

Growth and attributes: The integrated effect of organic and inorganic sources of nitrogen on plant height, number of tillers hill $^{-1}$ recorded at harvest is presented in Table 1.

Plant height $(\mathbf{c m})$ : The plant height differed significantly $(P \leq 0.05)$ due to different substitution ratios of nitrogen through organic sources with fertilizer. All the treatments receiving nitrogen through organic sources of VC, PM and FM at substitution ratios of 25,50 and 100 percent recorded significantly $(P \leq 0.05)$ higher plant height compared to control but were on par with each other and also recommended dose of nitrogen. The highest plant height $(92.27 \mathrm{~cm})$ was recorded in T4 where 50 per cent $\mathrm{N}$ was substituted by VC which was significantly $(P \leq 0.05)$ higher compared to control $(72.15 \mathrm{~cm})$ but was on par with $\mathrm{T} 2$ which received recommended dose of nitrogen $(84.26 \mathrm{~cm})$. This was followed by treatment T3- POP + 25 per cent $\mathrm{N}$ through VC $(90.40 \mathrm{~cm})$. Significant increase in plant height might be due to greater availability and steady release of nutrients from organic sources (VC, PM and FM), which perhaps enabled the recovery of plant height towards the reproductive stage. Norman et al., (2005) reported that vermicompost has the potential in enhancing the plant growth due to the changes in physicochemical properties of soils, overall increase in microbial activity and plant growth regulators produced by microorganisms.

Number of productive tillers hill $^{-1}$ : The number of productive tillers hill $^{-1}$ was significantly $(P \leq 0.05)$ influenced by the integrated application of organic and inorganic nitrogen sources. The maximum number of productive tillers hill $^{-1}$ was recorded in treatment T4POP with 50 per cent RDN through VC (16.85) followed by treatment with T6 -POP + 50 per cent RDN through PM (15.48) which were significantly $(P \leq 0.05)$ higher compared to control (9.23). Variations in the number of productive tillers hill $^{-1}$ among the different treatments were mainly due to their variations in the availability of nitrogen and other nutrients from the organic and inorganic sources supplied. Adequacy of nitrogen probably favoured the cellular activities during panicle formation and development that led to an increase in the number of bearing tillers. Miller (2007) reported that organic sources offer more balanced nutrition to the plants, especially micronutrients, which positively affect the number of tillers in plants.

Yield and yield attributes: The integrated effect of organic and inorganic sources of nitrogen on panicle length, grain yield and straw yield recorded at harvest are presented in Table. 1.

The panicle length was highly significant $(P \leq 0.05)$ for a different combination of organic and inorganic sources of nitrogen. Among the treatments, the high- est panicle length was recorded in T4 -POP with 50 per cent RDN through VC $(17.04 \mathrm{~cm})$ which was significant $(P \leq 0.05)$ compared to T1-control $(11.09 \mathrm{~cm})$ but was on par with treatment T6-POP +50 per cent RDN through PM $(16.60 \mathrm{~cm})$. The panicle length of the treatments receiving organic sources of nitrogen at different substitution ratios was on par with each other but was significantly $(P \leq 0.05)$ higher than control. The data on grain yield showed that significantly $(P \leq 0.05)$ higher grain yield $\left(5434 \mathrm{~kg} \mathrm{ha}^{-1}\right)$ was recorded in the treatment T4-POP+ 50 per cent $\mathrm{N}$ through VC followed by T6-POP +50 per cent $N$ through PM (5240 kg ha- ${ }^{-1}$ ) and T9 -100 percent $N$ through VC $\left(5123 \mathrm{~kg} \mathrm{ha}^{-1}\right)$ compared to T1-control (3541 $\mathrm{kg} \mathrm{ha}^{-1}$ ) but were on par with each other. The straw yield was significantly $(\mathrm{P}<0.05)$ higher in the treatment T4-POP+ 50 per cent $\mathrm{N}$ through VC (5434 $\left.\mathrm{kg} \mathrm{ha}^{-1}\right)$ compared to T1-control (3541.0 kg ha $\left.{ }^{-1}\right)$. This was followed by treatment receiving $\mathrm{T} 6-\mathrm{POP}+50$ per cent $\mathrm{N}$ through $\mathrm{PM}$, which recorded a grain yield of $5240 \mathrm{~kg} \mathrm{ha}^{-1}$ and treatment T9 - 100 percent VC (5123 kg ha- $\left.{ }^{1}\right)$. Higher yields in the treatment receiving $\mathrm{VC}$ might be due to increased availability of nutrients, presence of beneficial microflora and plant growth regulators like gibberellins, auxins etc. This might have provided balanced availability of nutrients to assimilate sufficient photosynthates for increased dry matter production by positive conversion of the source to sink reflecting in the form of more productive tillers, higher panicle length leading to higher grain and straw yield. Roy and Singh (2006) stated that increased growth and yield components of crops due to application of vermicompost was mainly because of microbial stimulation effect and $\mathrm{N}$ supplied through gradual mineralization in a steady manner throughout the crop growth period. Dekhane et al., (2014) from Maharashtra reported beneficial effect of vermicompost on growth and yield attributes of rice variety GR-11 when 50 percent of recommended nitrogen was substituted by vermicompost while Kyi moe et al., (2019) reported from China that integrating nitrogen through poultry manure at 50 percent of the recommended dose enhanced growth parameters and yields of rice. Paramesh et al., (2014) also reported that 50 per cent RDN through chemical fertilizers + 50 per cent RDN through vermicompost recorded significantly higher plant height, leaf area, number of tillers hill ${ }^{-1}$, total dry matter accumulation hill ${ }^{-1}$, grain yield and straw yield in rice. Manivannan and Sriramachandrasekharan (2016) recorded significantly higher grain and straw yield when 50 percent of recommended nitrogen was substituted by vermicompost compared to control but was on par with poultry manure substituted at 50 percent of the recommended nitrogen.

Post-harvest soil fertility status: The integrated effect of organic and inorganic sources of nitrogen on soil $\mathrm{pH}$, Electrical Conductivity (EC), Available Nitrogen $\left(\mathrm{Kg} \mathrm{ha}{ }^{-1}\right)$, Available Phosphorus $\left(\mathrm{Kg} \mathrm{ha}^{-1}\right)$ and 
Table 1. Effect of organic and inorganic sources of nitrogen on yield of rice during kharif season of 2017 (Values are average of three replications).

\begin{tabular}{lllllll}
\hline \multirow{2}{*}{$\begin{array}{l}\text { Sl. } \\
\text { No. }\end{array}$} & Treatments & \multicolumn{5}{c}{ Yield and yield attributes of rice } \\
\cline { 3 - 7 } & & $\begin{array}{l}\text { Plant height } \\
(\mathbf{c m})\end{array}$ & $\begin{array}{l}\text { Productive } \\
\text { tillers hill }\end{array}$ & $\begin{array}{l}\text { Panicle length } \\
(\mathbf{c m})\end{array}$ & $\begin{array}{l}\text { Grain yield } \\
\text { (kg ha }^{-1} \mathbf{)}\end{array}$ & $\begin{array}{l}\text { Straw yield } \\
\text { (kg ha }^{-1} \mathbf{)}\end{array}$ \\
\hline 1 & Control & 72.15 & 9.23 & 11.09 & 3541 & 4426 \\
2 & POP & 84.26 & 11.65 & 14.24 & 4586 & 5732 \\
3 & POP +25\% N through VC & 90.40 & 14.38 & 16.17 & 4732 & 5915 \\
4 & POP +50\% N through VC & 92.27 & 16.85 & 17.04 & 5434 & 6817 \\
5 & POP +25\% N through PM & 86.73 & 14.23 & 15.10 & 4680 & 5850 \\
6 & POP +50\% N through PM & 88.13 & 15.48 & 16.60 & 5240 & 6550 \\
7 & POP +25\% N through FM & 85.23 & 13.28 & 14.85 & 4554 & 5692 \\
8 & POP +50\% N through FM & 86.70 & 15.76 & 15.25 & 4784 & 5980 \\
9 & $100 \%$ N through VC & 87.41 & 14.50 & 16.39 & 5123 & 6403 \\
10 & $100 \%$ N through PM & 86.45 & 13.20 & 15.52 & 4935 & 6168 \\
11 & 100\% N through FM & 85.40 & 12.60 & 15.15 & 4886 & 6107 \\
& SEm \pm & 3.63 & 0.80 & 0.86 & 196 & 293 \\
& CD $(5 \%)$ & 10.48 & 2.34 & 2.54 & 576 & 859 \\
\hline
\end{tabular}

POP=Package of Practices : $\mathrm{VC}=$ vermicompost :PM= Poultry Manure :FM= Fish manure; Recommended dosage of fertilizers $=60: 30: 60 \mathrm{~kg} \mathrm{ha}^{-1} \mathrm{~N}, \mathrm{P}_{2} \mathrm{O}_{5}, \mathrm{~K}_{2} \mathrm{O}$

Available Potassium $\left(\mathrm{Kg} \mathrm{ha}^{-1}\right)$ at harvest during kharif season of 2017 are presented in Table-2.

Soil $\mathrm{pH}$ and EC: The $\mathrm{pH}$ and EC of the post-harvest soil samples varied within a narrow range among different treatments and the differences were statistically $(P \leq 0.05)$ non-significant.

The soil $\mathrm{pH}$ values were not significantly $(\mathrm{P}<0.05)$ influenced by the integrated nitrogen application through organic and inorganic sources in rice. However, the $\mathrm{pH}$ of the treatments varied from 5.02 to 5.29 indicated acidity of the soils. The highest $\mathrm{pH}$ value was recorded in treatment T10-100 percent PM (5.29) followed by treatment T6- 50 percent PM (5.22) and T850 per cent FM (5.22) The EC was not significantly $(P \leq 0.05)$ influenced by integrated application of organic and inorganic sources of nitrogen. However, the EC values ranged from $0.0440 \mathrm{dSm}^{-1}$ in control to 0.0537 $\mathrm{dSm}^{-1}$ in T-5 ( POP $+25 \% \mathrm{~N}$ PM). The acidity of the soil and low EC could be attributed to the high degree of leaching of bases, and soluble salts due to heavy rainfall of $2792 \mathrm{~mm}$ received from June to September 2017during the crop growth period. Sharma et al. (2013) reported a decline in soil $\mathrm{pH}$ due to the formation of organic acids by decomposition of organic manure and crop residues. Harikesh et al. (2017) concluding a two year experiment reported that integrated use of FYM along with fertilizers (50:50) in rice crop also reduced the soil $\mathrm{pH}$ faster as compared to inorganic fertilizers alone.

Available soil nitrogen $(\mathrm{N})$ : The soil available nitrogen was significantly $(P \leq 0.05)$ influenced by different treatment combinations of organic and inorganic sources of nitrogen in rice and was observed to be of medium availability in the soil. The treatment T4 (POP +50 per cent $\mathrm{VC})$ recorded significantly $(P<0.05)$ higher available nitrogen (382.36 kg ha-1) compared to control $\left(294.05 \mathrm{~kg} \mathrm{ha}^{-1}\right)$ but was on par with the treatment T3 (POP +25 per cent VC) which recorded $374.80 \mathrm{~kg} \mathrm{ha}^{-1}$ of available nitrogen. All the treatments, comprising combinations of organic and inorganic sources of nitrogen recorded significantly $(P \leq 0.05)$ higher available soil nitrogen as compared to T1control and T2-POP. The lowest soil available nitrogen was recorded in control $(294.05 \mathrm{~kg} / \mathrm{ha})$ followed by treatment T2 -POP ( $313.41 \mathrm{~kg} \mathrm{ha}^{-1}$ ). Vermicompost, poultry manure and fish manure might have attributed to the mineralization of $\mathrm{N}$ in soil and promoting of microbial activity. This may have resulted in the conversion of the organically bound nitrogen to inorganic form, which might have increased the transformation of nutrients to available form and improving $\mathrm{N}$ availability in soil. A similar increase in available $\mathrm{N}$ in soil due to addition of organics was observed in rice (Singh et al., 2006). Abhik et al. (2017) concluding a 10 year experiment in rice reported that INM treatments with enriched compost as well as bio-fertilizers had pronounced influence on improving available nitrogen status in acid soil and attributed it to narrowing down of $\mathrm{C}: \mathrm{N}$ ratio and enhanced rate of mineralization resulting in rapid conversion of organically bound $\mathrm{N}$ to inorganic forms which helped in release of nutrients. Harikesh et al. (2017) reported from Faizabad (UP) that regular application of $100 \%$ recommended doses of nitrogen either through various organic sources 
Table 2. Effect of organic and inorganic sources of Nitrogen on soil fertility status at harvest during kharif season of 2017 (Values are average of three replications).

\begin{tabular}{|c|c|c|c|c|c|c|}
\hline \multirow[b]{2}{*}{$\begin{array}{l}\text { SI. } \\
\text { No. }\end{array}$} & \multirow[b]{2}{*}{ Treatments } & \multicolumn{5}{|c|}{ Soil fertility parameters at harvest } \\
\hline & & $\mathrm{pH}$ & $\begin{array}{l}\mathrm{EC} \\
\left(\mathrm{dS} \mathrm{m}^{-1}\right)\end{array}$ & $\begin{array}{l}\text { Available } \\
\text { Nitrogen } \\
\text { (Kg/ha) }\end{array}$ & $\begin{array}{l}\text { Available } \\
\text { Phosphorus } \\
\text { (Kg/ha) }\end{array}$ & $\begin{array}{l}\text { Available } \\
\text { Potassium } \\
\text { (Kg/ha) }\end{array}$ \\
\hline 1 & Control & 5.04 & 0.0440 & 294.05 & 43.93 & 92.31 \\
\hline 2 & POP & 5.10 & 0.0510 & 313.41 & 65.25 & 125.1 \\
\hline 3 & $\mathrm{POP}+25 \% \mathrm{~N}$ through VC & 5.16 & 0.0486 & 374.80 & 66.26 & 132.6 \\
\hline 4 & $\mathrm{POP}+50 \% \mathrm{~N}$ through VC & 5.20 & 0.0480 & 382.36 & 68.23 & 143.7 \\
\hline 5 & $\mathrm{POP}+25 \% \mathrm{~N}$ through $\mathrm{PM}$ & 5.18 & 0.0537 & 358.73 & 70.23 & 134.8 \\
\hline 6 & $\mathrm{POP}+50 \% \mathrm{~N}$ through $\mathrm{PM}$ & 5.22 & 0.0513 & 365.11 & 78.83 & 141.8 \\
\hline 7 & $\mathrm{POP}+25 \% \mathrm{~N}$ through $\mathrm{FM}$ & 5.15 & 0.0523 & 352.30 & 62.30 & 128.4 \\
\hline 8 & $\mathrm{POP}+50 \% \mathrm{~N}$ through $\mathrm{FM}$ & 5.22 & 0.0527 & 356.75 & 68.50 & 132.8 \\
\hline 9 & $100 \% \mathrm{~N}$ through VC & 5.02 & 0.0493 & 352.60 & 56.46 & 131.6 \\
\hline 10 & $100 \% \mathrm{~N}$ through $\mathrm{PM}$ & 5.29 & 0.0447 & 348.20 & 60.13 & 138.3 \\
\hline \multirow[t]{3}{*}{11} & $100 \% \mathrm{~N}$ through $\mathrm{FM}$ & 5.23 & 0.0480 & 342.30 & 54.91 & 137.4 \\
\hline & $\mathrm{SEm} \pm$ & 0.13 & 0.01 & 8.40 & 3.35 & 2.09 \\
\hline & CD $(5 \%)$ & NS & NS & 24.91 & 9.85 & 6.14 \\
\hline
\end{tabular}

$\mathrm{POP}=$ Package of Practices $: \mathrm{VC}=$ vermicompost $: \mathrm{PM}=$ Poultry Manure $: F M=$ Fish manure; Recommended dosage of fertiliers $=60: 30: 60$ $\mathrm{kg} \mathrm{ha}^{-1} \mathrm{~N}, \mathrm{P}_{2} \mathrm{O}_{5}, \mathrm{~K}_{2} \mathrm{O}$

(FYM, VC) or chemical fertilizers alone or in the combination of both (FYM +fertilizer) enhanced available nitrogen content in soil by 15.25 percent in a span of two years.

Available phosphorus $\left(\mathbf{P}_{2} \mathbf{O}_{5}\right)$ : The available phosphorus $\left(\mathrm{kg} \mathrm{ha}^{-1}\right)$ in the soil after the harvest of rice was significantly $(P \leq 0.05)$ influenced by different treatment combinations of organic and inorganic sources of nitrogen. Treatment T6 (POP+ 50 per cent $\mathrm{PM}$ ) recorded significantly higher available phosphorus $\left(78.83 \mathrm{~kg} \mathrm{ha}^{-1}\right)$ compared to T1- control $(43.93 \mathrm{~kg}$ $\left.\mathrm{ha}^{-1}\right)$ and T2- POP (65.25 $\left.\mathrm{kg} \mathrm{ha}^{-1}\right)$ but was on par with treatment T5-POP+per cent PM $\left(70.23 \mathrm{~kg} \mathrm{ha}^{-1}\right)$. The treatments T3- POP+25 per cent VC $\left(66.26 \mathrm{~kg} \mathrm{ha}^{-1}\right)$, T4- POP+50 per cent VC $\left(68.23 \mathrm{~kg} \mathrm{ha}^{-1}\right)$, T7$\mathrm{POP}+25$ per cent FM $\left(62.30 \mathrm{~kg} \mathrm{ha}^{-1}\right)$ and T8POP+50 per cent FM $\left(68.50 \mathrm{~kg} \mathrm{ha}^{-1}\right)$ were on par with each other. However, the available phosphorus content recorded with absolute control was significant$\mathrm{l}(\mathrm{P} \leq 0.05) \quad$ lower than the rest of the treatments. Higher availability of soil phosphorus in T6 might be due to coating of sesquioxides by organic materials that reduced $\mathrm{P}$-fixation in soil and promoted release of carbon dioxide and organic acids solubilizing the native soil phosphorus. Laxminarayana (2006) also found that combined use of organics (green manure/ FYM/poultry manure/pig manure) along with inorganic fertilizers in rice increased nutrient use efficiency and available $\mathrm{P}$ content in the soil. Kiran et al. (2018) reported that application of RDF+ vermicompost +PSB+ 25 per cent nitrogen through glyricidia increased the available phosphorus ( $\left.86.95 \mathrm{~kg} \mathrm{ha}^{-1}\right)$ and attributed it to release of organic acids during the decomposition of organic matter, which helped in the solubility of native phosphates as a result of which the available phosphorus content in the soil increased.

Available potassium $\left(\mathbf{K}_{\mathbf{2}} \mathbf{O}\right)$ : The available potassium was significantly $(P \leq 0.05)$ higher in the treatment $T 4$ POP+50 per cent VC (143.7 kg ha $\left.{ }^{-1}\right)$ compared to treatment T1-control (92.31 kg ha-1). This was followed by treatment T6 POP+50 per cent PM (141.8 $\left.\mathrm{kg} \mathrm{ha}^{-1}\right)$. The treatment T2- POP (125.1 kg per ha-1) was on par with T7-POP +25 per cent FM (128.4 kg per ha-1) but was significantly $(P \leq 0.05)$ higher than control. The beneficial effect of VC on available potassium might be due to the reduction of $\mathrm{K}$ fixation, solubilizing action of certain organic acids produced during decomposition and its greater capacity to hold $\mathrm{K}$ in the available form, thereby increasing absorption of $\mathrm{K}$. Prasad et al., (2010) also reported beneficial effect of vermicompost on residual soil fertility because of slow release of nutrients and reduction of nutrient losses. Jakasaniya et al. (2019) reported that application of 100 percent of nitrogen through the organic source of castor cake recorded significantly higher available soil potassium after harvest of the rice crop and attributed to direct addition of potash in available $\mathrm{K}$ pool of the soil which ultimately improved the availability of $\mathrm{K}$ at harvest.

\section{Conclusion}

The high cost of fertilizers and unstable crop production need for substituting the part of the inorganic fertilizers by locally available low-cost organic sources in an integrated manner for sustainable production. The present study concluded that the soil $\mathrm{pH}$ and $\mathrm{EC}$ were not significantly influenced by the integrated applica- 
tion of organic and inorganic sources of nitrogen in rice (Oryza sativa $\mathrm{L})$. However available nitrogen $((\mathrm{kg}$ $\left.\mathrm{ha}^{-1}\right)$, available phosphorus ( $\left.\mathrm{kg} \mathrm{ha}^{-1}\right)$, and available potassium $\left(\mathrm{kg} \mathrm{ha}^{-1}\right)$ in the soil, as well as growth and yield attributes of rice, were significantly $(P \leq 0.05)$ influenced by integrated application of nitrogen in rice. The treatment of POP with 50 per cent RDN through $V C$ recorded significantly $(P \leq 0.05)$ higher plant height, productive tillers hill $^{-1}$, panicle length, grain yield and straw yield at harvest compared to control and had a beneficial effect on soil fertility status at harvest. Thus, there is a need for the integrated use of 50 per cent RDN with VC to meet the nutrient requirement of rice for sustaining its higher productivity in coastal Karnataka.

\section{Conflict of interests}

The authors declare that they have no conflict of interests.

\section{REFERENCES}

1. Anonymous (2015). Agricultural Statistics at a Glance. Government of India, Directorate of Economics and Statistics Ministry of Agriculture and Farmer Welfare (DACFW-GOI). pp 48

2. Anonymous (2017). Agricultural Statistics at a Glance. Government of India, Directorate of Economics and Statistics Ministry of Agriculture and Farmer Welfare (DACFW-GOI) pp.36.

3. Anonymous (2018). FAO- Rice Market Monitor Food and Agricultural Organization-United Nations., Rome, Italy. 21:1-2.

4. Abhik, P., Sharma, V. K., Purakayastha, T. J., Barman, Mandira Kumar, Sarvendra, Chakraborty, D., Chobhe, Kapil A. and Nath, D. J. (2017). Effect of Integrated Nutrient Management in Rice on Nitrogen Availability, L-asparaginase and L-glutaminase Activity in Acidic Soil. International Journal of Current Microbiology and Applied Sciences, 6(9): 3777-3783. doi: https://doi.org/10.20546/ ijcmas.2017.609.466

5. Dahiphale, A. V., D. G., Giri, Thakre, G. V. and Gin, M. D. (2003). Effect of Integrated Nutrient Management on Yield and Yield Contributing Parameters of the Scented Rice. Annals of Plant Physiology, 17 ( 1) 24-26.

6. Dekhane, S. S., Patel, D. J., Jadhav, P. B., Kireeti, A., Patil, N. B., Harad, N. B. and Jadhav, K. P. (2014). Effect of organic and inorganic fertilizer on growth and yield of paddy cultivar GR-11. International Journal of Information Research and Review, 1(2) : 026-028.

7. Gomez. K. A. and Gomez. A. A. (1984). Statistical Procedures for Agricultural Research $2^{\text {nd }}$ Edition New York. J. Wiley and Sons.

8. Gobi, S., Balasubramanian, S. and Elayaraja (2016). The effectiveness of organic and inorganic soil amendments on low land rice performance. 5th International Conference on Agriculture, Environment and Biological Sciences (ICAEBS-16) April 28-29, 2016 Pattaya (Thailand) pp.42-46.

9. Harikesh, Akhtar Ali, Ghanshyam Singh, Sanjay Kumar, Shivam, Ravi, Pratap Yadav, Ankit Tiwari, Ajit. Kumar and Atul Yadav (2017). Effect of integrated nutrient management and plant geometry on soil properties and avail- ability of nutrients under SRI technique of rice. Journal of Pharmacognosy and Phytochemistry 6 (5): 86-89

10.Jakasaniya, M. S., Kiranben J. Khokhariya, R. D. Shinde and Astha Pandey (2019). Effect of Integrated Nitrogen Management on Yield of Rice and Chemical Properties of Sodic Soil. International Journal of Current Microbiology and Applied Sciences. 8(05): 1289-1296. doi: https:// doi.org/10.20546/ijcmas.2019.805.147

11.Kiran, K., C. J. Sridhara and K. M. Nandini (2018). Effect of integrated use of organic and inorganic fertilizers on soil fertility and uptake of nutrients in aerobic rice (Oryza sativa L.) International Journal of Chemical Studies, 6 (4): 417-421.

12.Kyi Moe, Seinn Moh Moh, Aung Zaw Htwe, Yoshinori Kajihara and Takeo Yamakawa (2019). Effects of Integrated Organic and Inorganic Fertilizers on Yield and Growth Parameters of Rice Varieties Rice Science, (5): 309 -318. https://dx.doi.org/10.1016/j.rsci.2019.08.005

13.Laxminarayana, K. (2006). Effect of integrated use of inorganic and organic manures on soil properties, yield and nutrient uptake of rice in Ultisols of Mizoram. Journal of the Indian Society of Soil Science, 54 (1): 120-123.

14.Miller. H. B. (2007). Poultry litter induces tillering in rice. Journal of Sustainable Agriculture, 31: 1-12.

15.Manivannan, R. and Sriramachandrasekharan, M. V. (2016). Integration of Organics and Mineral N on Growth and Yield of Rice in Typic Ustifluvents Soil. International Journal of Current Microbiology and Applied Sciences, 5 (12):428-436.Doi:http://dx.doi.org/10.20546/ijcmas.201 6.512 .047

16.Nayak. A. K., S Mohanty D Chatterjee, D Bhaduri, R Khanam, M Shahid, R Tripathi, A Kumar, S Munda, U Kumar, P Bhattacharyya, BB Panda and H Pathak. (2018). Nutrient Management for Enhancing Productivity and Nutrient Use Efficiency in Rice In: Rice Research for enhancing productivity and profitability and climate resilience. Published by ICAR- National Rice Research Institute, Cuttack-753006, Odisha, India.

17.Norman, Q.A., Edwards, C.A., Bierman. P., Metzger, J.D., and Lucht, C. (2005). Effects of vermicomposts produced from cattle manure, food waste and paper waste on the growth and yield of peppers in the field. Pedobiologia, 49 : 297-306.

18.Paramesh, V., C.J. Sridhara, K.S. Shashidhar and S. Bhuvaneswari (2014). Effect of integrated nutrient management and planting geometry on growth and yield of aerobic rice. International Journal of Agricultural Sciences, 10 (1): $49-52$.

19.Prathap R. N., CH. Bharat Bhushan Rao, K.Surekha and Hussain, S.A. (2019). Transplanted rice as influenced by different enriched nitrogen sources-an economic appraisal. International Journal of Current Microbiology and Applied Sciences, 8(6): 3229-3231. doi: https://doi.org/10.2 0546/ijcmas.2019.806.384

20.Prasad. J., Karmakar. S., Kumar. R., and Mishra, B (2010). Influence of integrated nutrient management on yield and soil properties in maize-wheat cropping systems in an Alfisol of Jharkhand. Journal of Indian Society of Soil Science, 58(2): 200-204.

21.Prasad. R. (2011). Aerobic Rice Systems. Advances in Agronomy, 207-247. https://doi.org/10.1016/ B978-0-12387689-8.00003-5

22.Prasad. R., Pathak H., Patra A K. and Shivay Y. S. (2014). Nitrogen Management In: Text book of Plant Nutrient Management Editors.-Prasad. R, Kumar, D Ra- 
na, D. Shivay Y. S. and Tewatia. Publisher Indian Society of Agronomy, IARI, New Delhi.pp.73-92.

23.Roy, D. K. and Singh, B. P. (2006). Effect of level and time of nitrogen application with and without vermicompost on yield and yield attribute and quality of malt barley (Hordeum vulgare). Indian Journal of Agronomy, 51(1): 40 $-42$.

24.Sharma, G. D., Risikesh, T., Som Raj, D. L. Kauraw and P. S. Kulhare (2013). Impact of integrated nutrient management on yield, nutrient uptake, protein content of wheat (Triticum aestivam) and soil fertility in a typic haplustert The Bioscan 8 (4): 1159-1164.

25.Shipra, Y., Mohan Lal., R. K. Naresh, R. B. Yadav, Ashok Kumar Yadav, K. G. Yadav, Rahul Kumar, M. Sharath Chandra and Pradeep Rajput (2019). Effect of organic and inorganic nutrient sources on productivity, grain quali- ty of rice and rice health in North Western IGP: A Review. International Journal of Current Microbiology and Applied Sciences, 8(12): 2488-2514. doi: https://doi.org/10.20546/ ijcmas.2019.812.293

26.Singh Surendra, Singh, R. N., Prasad, Janardan and Singh, B. P. (2006). Effect of integrated nutrient management on yield and uptake of nutrients by rice and soil fertility in rainfed uplands. Journal of the Indian Society of Soil Science, 54(3): 327-330

27.Surekha, K. R., Mahendra Kumar, V., Nagendra. N., Sailaja, T. Satyanarayana (2016). 4R nitrogen management for sustained rice production. Better crops- South Asia, 10(10-1): 18-19.

28.Tumrani S A., Pathan. P A. and Suleman B M. (2015). Economic contribution of rice production and food security in Indonesia Asia Pacific Research Journal, 33: 63-74. 